\title{
MOLECULAR ASPECTS OF ESOPHAGEAL SQUAMOUS CELL CARCINOMA CARCINOGENESIS
}

\author{
Dárcio Matenhauer LEHRBACH, Marcelo Eidi NITA, Ivan CECCONELLO and \\ Clinical Genomics of Esophageal Cancer Group*
}

\begin{abstract}
Background - The development of human esophageal cancer is a multistep, progressive process. An early indicator of this process is an increased proliferation of esophageal epithelial cells morphologically including basal cell hyperplasia, dysplasia, carcinoma in situ and advanced esophageal squamous cell carcinoma. The process of tumorigenesis at cellular level is related to disorders of the control of cell proliferation and differentiation and controlled cell death (apoptosis). Most of cancer cells contain genetic alterations related to the control of these processes, including transcription factors and apoptosis related proteins. Aim - In this review, the current knowledge of the genetic profile of this subtype of esophageal tumor is discussed, focusing on the potential of the development of novel tools for clinical management of esophageal squamous cell carcinoma. Conclusions - The advances in the field of molecular biology have let us to deeper our knowledge of the process of carcinogenesis of esophagus. Ideally, this knowledge should be translated in benefits for patients suffering from cancer. Thus, better understanding of molecular alterations during carcinogenesis is expected to improve tumor control and prevention and also may lead to better disease management.
\end{abstract}

HEADINGS - Esophageal neoplasms, surgery. Carcinoma, squamous cell. Genes 53. Cell cycle. Apoptosis.

\section{INTRODUCTION}

Esophageal carcinoma, one of the most malignant gastrointestinal cancers, occurs at a high frequency rate in Asia and South America. In fact, the incidence of esophageal cancer varies largely among regions ${ }^{(13,21)}$ and high-risk areas include the eastern Asia, western and northern China, Hong Kong, Japan, southeastern Africa, France and South America regions (Brazil and Bermudas). The incidence and the prognosis of esophageal cancer seems to be worst in men as compared with women, and it might be the effect of different exposure to exogenous agents, like smoking. The development of human esophageal cancer is a multistep, progressive process. An early indicator of this process is an increased proliferation of esophageal epithelial cells morphologically including basal cell hyperplasia, dysplasia, carcinoma in situ and advanced esophageal squamous cell carcinoma (ESCC). The Brazilian Consensus on Gastroesophageal
Reflux Disease ${ }^{(20)}$ considers gastroesophageal reflux disease to be a chronic disorder related to the retrograde flow of gastroduodenal contents into the esophagus, with or without tissue damage. From these stages of disease it is possible to evolve to esophageal adenocarcinoma, which are increasingly being diagnosed. However, this review will focus on the esophageal squamous cell carcinoma, which is predominant throughout the world and it is characterized by high mortality rate ${ }^{(13)}$.

The process of tumorigenesis at the cellular level is related to disorders of the control of cell proliferation and differentiation and controlled cell death (apoptosis). In this process, multiple genetic alterations are involved, including mutation of the p53 gene, amplification of cyclin D1 gene, among others ${ }^{(1,27,27,29,30,31)}$. Most of the cancer cells contain genetic alterations that related to the control of these process, including transcription factors, such as $\mathrm{p} 53$, and apoptosis related proteins ${ }^{(16,18)}$. Two basic type of genetic damage are

\footnotetext{
* The components of the Clinical Genomics of Esophageal Cancer Group are Maria Fernanda Pimentel de Carvalho, Alexandre Muxfeldt Ab'Saber, Venâncio Avancini Ferreira Alves and Joaquim Gama-Rodrigues.

Gastroenterology Dept., School of Medicine, University of São Paulo.

Address for correspondence: Dr. Marcelo Eidi Nita - Av. Francisco Matarazzo, 1400, 13º andar, Ed. Milano - 05001-903 - São Paulo, SP, Brazil.

E-mail: marcelo_nita@uol.com.br
} 
encountered frequently in cancer cells: dominant (with targets known as oncogenes) and recessive (with targets known as tumor suppressor genes). The genetic events affecting oncogenes often result in increased stimulatory function, whereas those affecting tumor suppressor genes may cause loss of inhibitory function.

There are several major biochemical mechanisms of action for oncogenes: 1 . abnormal signaling by a structurally abnormal cytokine/ growth factor including amplification, deletion, rearrangement and point mutation of the gene; 2 . aberrant phosphorylation of proteins at either serine, threonine or tyrosine residues by altered receptors and other signal transducing kinases; and 3. disturbed regulation of gene transcription by abnormal transcription factors.

Tumor suppressor genes can be defined as genes whose inactivation - by mutation, methylation or chromossomal loss, results in cell transformation. The advances in the field of molecular biology have let us to deeper our knowledge of the process of carcinogenesis of the esophagus (Table 1). Ideally, this knowledge should be translated in benefits for patients suffering from cancer. However a new class of gene to have any clinical meaning has to have a clear role in at least one of these fields of cancer management: 1) prevention; 2) diagnosis; 3) prediction of prognosis; or 4) treatment. Thus, better understanding of the molecular alterations during carcinogenesis is expected to improve tumor control and prevention and also may lead to better disease management. In this review, the current knowledge of the genetic profile of this subtype of esophageal tumor is discussed, focusing on the potential of the development of novel tools for clinical management of ESCC.

TABLE 1 - Location of the main genes involved with ESCC

\begin{tabular}{|c|c|c|}
\hline Gene & Chromosomal localization & Alternative titles, symbols \\
\hline c-myc & $8 \mathrm{q} 24.12-\mathrm{q} 24.13$ & --- \\
\hline Cyclin D1 & $11 \mathrm{q} 13$ & PRAD-1, CCND1, EXP2, bcl-1 \\
\hline mdm2 & $12 \mathrm{q} 14.3-\mathrm{q} 15$ & murine double minute 2, p53-binding protein MDM2 \\
\hline \multicolumn{3}{|c|}{ Anti-oncogenes } \\
\hline p53 & $17 \mathrm{p} 13.1$ & Transformation-related protein 53, TP53 \\
\hline $\mathrm{p} 21$ & $6 \mathrm{p} 21.2$ & $\begin{array}{l}\text { CDK-interacting protein } 1 \text {; CDKN1A; CIP1; wildtype p53-activated } \\
\text { fragment } 1 \text {; WAF1 }\end{array}$ \\
\hline $\mathrm{p} 16$ & $9 \mathrm{p} 21$ & $\begin{array}{l}\text { CDKN2A; CDK4A inhibitor; multiple tumor suppressor 1; } \\
\text { MTS1; TP16; p16(INK4); p14(ARF) }\end{array}$ \\
\hline p27 & $12 \mathrm{p} 13$ & KIP1 \\
\hline
\end{tabular}

\section{TUMOR SUPPRESSOR GENES}

\section{p53}

The p53 tumor supressor gene has an open reading frame of 393 amino acids long, located at the short arm of human 17 chromosome. This protein plays an important role in the cellular integrity ${ }^{(14)}$ supressing the oncogenic transformation by interruption of the G1 phase of cellular cycle, given time for repairing the damage of DNA or apoptosis induction if the damage is too severe to be repaired ${ }^{(6,7,9,15)}$. Loss of p14 or amplification of MDM2 is associated with lack of p53 mutation ${ }^{(34)}$. These alternative mechanisms for p53 degradation occurs by binding to overexpressed MDM2 or by loss of p14 expression that should result in hyperactive MDM2 and enhanced degradation of p53 (Figure 1).

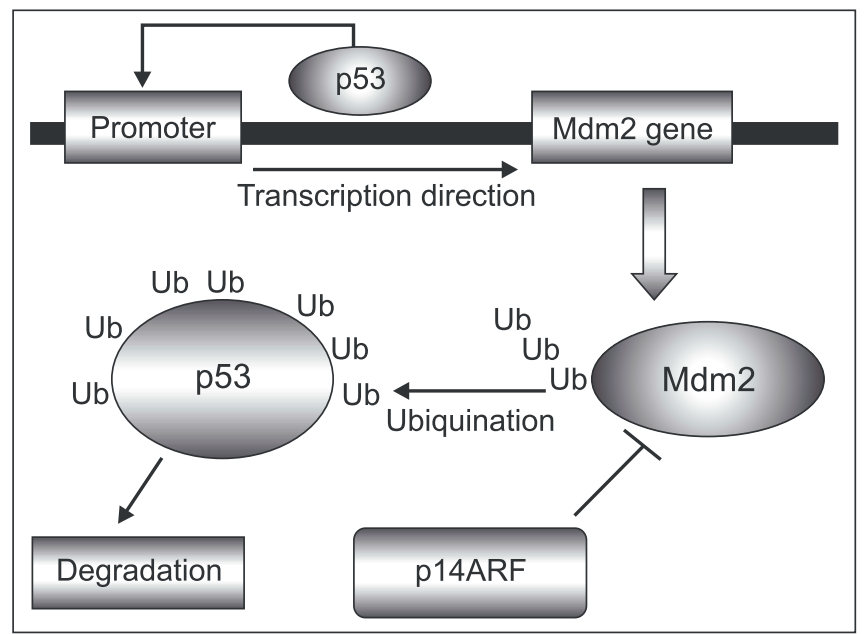

FIGURE 1 - Mechanism of p53 normal ubiquitination and degradation 
Mutations in the p53 gene occur in approximately $50 \%$ of all human tumors. VOGELSTEIN and KINZLER ${ }^{(41)}$, in 1992 outlined five mechanisms for p53 inactivation. It is postulated to bind as a tetramer to a p53-binding site (PBS) and to activate the expression of adjacent genes that inhibit growth and/or invasion. Deletion of one or both p53 alleles reduces the expression of tetramers, resulting in decreased expression of the growth inhibitory genes, mechanism found in occasional tumors of several types. Second, nonsense or splice site mutations that result in truncation of the protein do not allow oligomerization, thus resulting in a similar reduction of p53 tetramers. Mutations of this type are fairly common in cancers of lung and esophagus, among others. A third mechanism involves missense mutations resulting in dominant-negative effects (those that produces such negative effect over any other, independent on the allele) with an even greater reduction of functionally active tetramers. Such missense mutations are common in colon, brain, lung, breast, skin, bladder, and other cancers. A fourth mechanism by which p53 is involved in oncogenesis is common in cervical cancers where the expression of the E6 gene of human papillomavirus (HPV) results in the functional inactivation of p53 through binding and degradation. The p53 pathway may also be disrupted by alteration of a cellular gene MDM2 (Figure 1). The MDM2 gene is amplified in the significant fraction of the most common human sarcomas and the consequent over expression of MDM2 is likely to interfere with p53 activity ${ }^{(28)}$.

El-DEIRY et al. ${ }^{(6)}$ suggested the following model for p53 function: p53 is not required for normal development, but in certain cellular environments (DNA damage, cellular stress), its expression is stimulated. In turn, it binds to WAF1 regulatory elements and transcriptionally activates its expression. The WAF1 protein subsequently binds to and inhibits cyclin-dependent kinase activity, preventing phosphorylation of critical cyclin-dependent kinase substrates and blocking cell cycle progression. In tumor cells with inactive $\mathrm{p} 53$, this pathway would thereby be defective, permitting unregulated growth.

CARON de FROMENTAL and SOUSSI ${ }^{(4)}$ have detected point mutations basically in a high conserved region between exons 5 and 9. These altered expression, however, do not correlates with clinical-pathological parameters such as tumoral invasion, lymph nodes metastasis or venus and lymph invasion, what suggests that these mutations can be closely related with a first stage of pre-invasive esophageal carcinoma, playing an important role in the carcinogenesis of human esophageal tumor ${ }^{(5,13)}$.

RIBEIRO et al. ${ }^{(33)}$ have studied tissue sections of patients with esophageal carcinoma that were stained immunohistochemically for p53 protein followed by topographic genotyping by direct sequencing of p53 exons 5-8. Sixty per cent of the tumors were p53 immunopositive, however only $40 \%$ were proven to contain $\mathrm{p} 53$ point mutational damage in exons $8,5,7$, and 6 . These results leads to the conclusion that histopathologic/genetic analysis is a better determinant of p53 mutational damage than immunohistochemistry alone and can be used as a prognostic marker for esophageal carcinoma.

These events of interaction among genes and their functions in carcinogenesis of the esophageal mucosa have contributed to elucidation of how the genetic alterations could lead to ESCC and in a near future may help the physicians to evaluate the clinical and pathological evolution of this kind of cancer by a new and more accurate personal diagnosis and prognosis system.

\section{p21 (waf1/cip1)}

p21(waf1/cip1), an important regulator of the cell cycle, binds to PCNA and acts as a mediator of the growth suppressing and apoptosis promoting functions of $\mathrm{p} 53^{(36)}$. Also known as CDKN1A, its protein inhibits cyclin-kinase activity, is tightly regulated at the transcriptional level by $\mathrm{p} 53$, and probably serves as the effector of p53 cell cycle control ${ }^{(3)}$.

In the cell, p53 protein binds DNA, which in turn stimulates the p21 expression that interacts with a cell division-stimulating protein (cdk2) forming a complex that cannot pass through to the next stage of cell division. Mutant p53 can no longer bind DNA in an effective way, hence the $\mathrm{p} 21$ protein is not available to act as the stop signal for cell division, and uncontrolled cell growth can culminate with tumors (Figure 2).

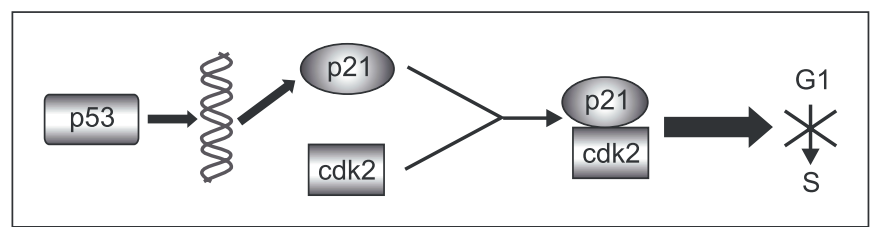

FIGURE 2 - Mechanism of p21 stop signal

In 1999, NITA et al. ${ }^{(23)}$ have studied the expression of p21, p27, $\mathrm{p} 53$, and $\mathrm{pRb}$ by immunohistochemical method in specimens from patients with curatively resected ESCC tumors and scored by a computerized image analysis system. They have verified that $\mathrm{p} 27$, $\mathrm{p} 53$, and $\mathrm{pRb}$ were not correlated with overall survival. Multivariate analysis showed that age, lymph node involvement, and p21 were independent prognostic factors, leading the authors to conclude that the expression of p21 is an independent prognostic factor in ESCC.

BAHL et al. (2) related the frequency of p21 variants in ESCCs with wild-type p53 and it was significantly higher than in tumors with p53 mutations, suggesting that this polymorphism affects the p53 pathway and may play an important role in esophageal tumorigenesis. 


\section{p14 (ARF) and p16 (INK4a)}

It was shown that $\mathrm{p} 14 \mathrm{ARF}$ and $\mathrm{p} 16 \mathrm{INK} 4 \mathrm{a}$ play active roles in the $\mathrm{p} 53$ and $\mathrm{pRb}$ tumor suppressive pathways. The tumor suppressor gene p16, also known as CDKN2 or CDK4-inhibitor, is located on chromosome 9p21, a frequent site of loss of heterozygocity ( $\mathrm{LOH})$ in many human malignancies. Its gene product acts as a negative regulator of cellular proliferation by interacting with cyclin-dependent kinase 4 (CDK4) and inhibiting its kinase activity whereas p14 binds the MDM2 proto-oncogene and stabilizes $\mathrm{p} 53^{(35)}$. The frequent deletion or mutation of CDKN2A in tumor cells corroborates with the idea that p16 acts as a tumor suppressor, because in the absence of functional p16, CDK4 binds to cyclin-D, which stimulates the passage through the G1 phase of the cell cycle ${ }^{(17)}$.

In ESCC, the primary mechanism underlying the loss of p16 is rare and point mutations are detected in only a minority of samples with $\mathrm{LOH}$. Immunohistochemical analysis of p16 and pRb proteins was carried out in paraffin-embedded sections from surgically resected ESCCs and matched normal tissues ${ }^{(32)}$. Ninety-seven percent of the cases showed aberration(s) in either or both of these proteins confirming their critical role in esophageal tumorigenesis.

Methylation of the $\mathrm{CpG}$ island within the $\mathrm{p} 16$ promoter prevents transcription and subsequent translation of the 16 protein $^{(19)}$. XING et al. ${ }^{(42,43)}$ have found aberrant promoter methylation of the $\mathrm{p} 16$ gene in $40 \%$ of the ESCC samples analyzed and concluded that p16 is the hotspot of hypermethylation of the $9 \mathrm{p} 21$ gene cluster.

More recently, important studies of potential target genes for prognosis were conducted. KATO et al. ${ }^{(12)}$ showed that in $\mathrm{pRb}$ positive primary esophageal cancers the p16 were negative. In 2001, STURM et al. ${ }^{(38)}$ presented a combined analysis of BAX and p16 in ESCC and showed subgroups with favorable ( $\mathrm{p} 16 / \mathrm{BAX}$ high expressing) or poor prognosis (loss of $\mathrm{p} 16 /$ loss of BAX). Taken together, these studies show several alterations of these genes in ESCC and indicate that they may be determinant of clinical outcome. Clearly, more elaborate prospective clinical studies delineating the true role of these genes in the clinical practice are required.

\section{Oncogenes}

\section{Cyclin D1}

Also known as PRAD1 or bcl-1, the cyclin D1 gene encodes a protein of 295 amino acids with similarities sequence to the cyclins. Cyclin D1 is known to play important roles in the G1/S checkpoint of the cell cycle.

There are evidences from in vitro and in vivo studies that cyclin D1 is associated with esophageal carcinogenesis process ${ }^{(1)}$. In fact,
FUJII et al. ${ }^{(8)}$ showed by flow cytometric analysis that increased expressions of cyclin D1 were found in esophageal cancer cell lines.

In 2001, IAMAMURA et al. ${ }^{(10)}$ studied the correlation between e-cadherin and cyclin-D1 expressions in ESCC. The combinatory analysis of these genes showed that patients who presented e-cadherin preservation and absence of cyclin-D1 had the best prognosis, and those who presented reduced e-cadherin and presence of cyclin-D1 had a poor prognosis. In 1999, TETSU and McCORMICK ${ }^{(40)}$ showed that $\beta$-catenin activates the cyclin-D1 promoter transcription and that cells which express the mutant $\beta$-catenin produces high levels of messenger RNA of cyclin-D1 and protein constitutively. They also showed that different levels of $\beta$-catenin leads to an accumulation of cyclin-D1 that contributes to neoplasic transformation, and that fact was confirmed by NAGASAWA et al. ${ }^{(22)}$ whose reported that over expression of cyclin-D1 protein is a frequent event in esophagus cancers.

\section{Apoptosis genes}

Apoptosis is a genetically programmed cell death, which plays an important role to limit the cell growth and maintain tissue homeostasis. Disruption of apoptosis control can lead to unlimited cell growth and promote carcinogenesis. Moreover, recent studies have shown that anti-cancer reagents eliminate cancer cells by activating apoptosis pathway, suggesting that molecular change to suppress apoptosis could be associated with drug resistance.

Bcl-2 family proteins, such as Bcl-XL, Bax, Bad and Bak, share significant homology and play a critical role to control apoptosis ${ }^{(25,26)}$. Bcl-2 and Bcl-XL suppress apoptosis, while Bax, Bad and Bak promote it. Few studies have evaluated systematically the potential of Bcl-2 family proteins for clinical use in digestive tract cancer field $^{(18)}$. Imbalance of cell proliferation due to alteration of cell cycle and apoptosis regulators can contribute to neoplastic growth, thus they may have prognostic importance in ESCC. Our group have examined the expression pattern of apoptosis regulators, Bcl-2, Bax and $\mathrm{Bcl}-\mathrm{XL}$ and determined the prognostic significance of Bcl-2 family proteins in combination with cell cycle regulators (p21, p53, p27 and pRb) and clinicopathological parameters in $\operatorname{ESCC}^{(23,24)}$. Univariate and multivariate analyses were performed to assess the association between these molecular markers and prognosis. A clinicopathologic molecular stage system is proposed based on the results of the multivariate analysis. Low Bcl-2 expression significantly correlated with younger ages and depth of tumor invasion. Ageadjusted survival analysis indicated that Bcl-2 was associated with survival in younger patients. p21 expression group was also associated with survival. On the other hand, Bax, Bcl-XL, p27, p53 and pRb were not correlated with overall survival. The multivariate analysis revealed that lower age, $\mathrm{pN}=0$, high $\mathrm{p} 21$ and high $\mathrm{Bcl}-2$ expression groups were favorable prognosis markers. 
A new staging system, which includes clinicopathological factors and molecular markers, is proposed. Groups of low-risk of death due to ESCC with all four favorable markers and high-risk with no favorable markers were identified. Our data suggest that combined analysis of classical clinicopathological parameters with two major pathways, cell cycle and apoptosis, involved in cancer progression are correlated to prognosis of ESCC patients and thus may be useful for more detailed and accurate staging of this type of tumor.

IKEGUCHI et al. ${ }^{(11)}$ have found that the loss of Bax expression was detected more frequently in p53-positive tumors.

\section{Methylation}

Hypermethylation, mainly at the promoter region of a given gene, may lead to transcriptional silencing of the methylated gene with loss of protein expression, and this process has increasingly being cited in many different human cancers. The mechanism of DNA methylation consists in the production of altered 5-methylcytosine molecule by the action of the DNA methyltransferases enzymes (DNMT 1, 3a or 3b), which catalyse the transfer of a methyl group (CH3) from S-adenosylmethionine (SAM) to carbon-5 position of cytosine molecule (Figure 3 ).

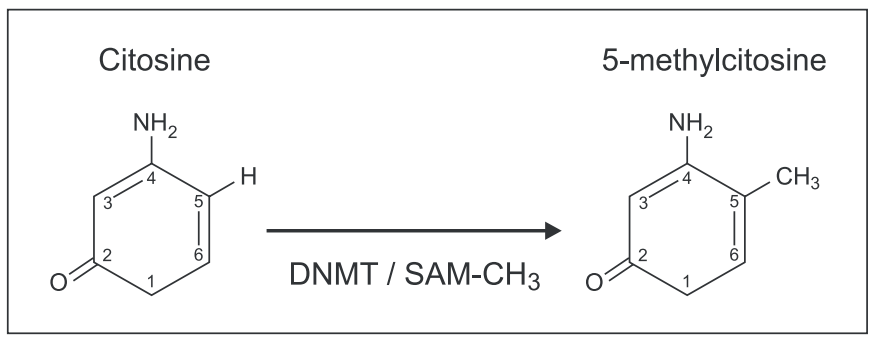

FIGURE 3 - Mechanism of DNA methylation
The importance of methylation forms of genes related to ESCC, from the Wnt signalling pathway or p53 network have been well demonstrated by several publications. The DNA methylation of the $\mathrm{CpG}$ islands (genome regions with high levels of citosineguanine repeates) at the promoter regions of e-cadherin have been proposed as a mechanism of its inactivation in human tumors ${ }^{(44)}$. SI et al. ${ }^{(37)}$ showed that $\mathrm{CpG}$ island methylation is common in esophageal carcinoma and may play an important role in downregulation of E-cadherin.

The p53 network, including the p16 gene, is another example of methylation-associated inactivation of putative tumor suppressor genes. TANAKA et al. ${ }^{(39)}$ have showed hypermethylation in $93 \%$ of the ESCC cell lines examined. XING et al. ${ }^{(43)}$ have performed multiple molecular analyses in ESCC specimens from Linxian, China using DNA methylation assay, LOH analysis, deletion screening and SSCPsequencing and they observed that 16 inactivation was predominantly associated with aberrant methylation in the $\mathrm{CpG}$ island of its promoter region. These results suggests that the two genes were inactivated by distinct mechanisms.

\section{CONCLUSIONS}

The molecular aspects of the carcinogenesis of ESCC in humans have been largely studied recently. With the improvement of the molecular biology techniques it was possible to complement the traditional approaches in diagnosis of ESCC, showing that it will be possible to apply these molecular knowledge for the clinical care and treatment soon. The collaboration between the various scientific and clinical disciplines in molecular research in ESCC should allow controlled trials to the better understanding of the mechanisms underlying tumor progression in ESCC so that improved diagnosis and therapy can be facilitated.

Lehrbach DM, Nita ME, Cecconello I, Clinical Genomics of Esophageal Cancer Group. Aspectos moleculares da carcinogênese do carcinoma epidermóide do esôfago. Arq Gastroenterol 2003;40(4):256-261.

RESUMO - Racional - O desenvolvimento do câncer de esôfago humano é um processo progressivo de diversas etapas. Um indicador precoce deste processo é o aumento na proliferação das células epiteliais esofágicas, incluindo alterações morfológicas, como hiperplasia das células basais, displasia, carcinoma in situ e carcinoma avançado de células escamosas do esôfago. Ao nível celular, o processo de carcinogênese está relacionado com alterações no controle de proliferação celular, diferenciação e morte celular programada (apoptose). A maioria das células tumorais contém alterações genéticas que se relacionam com o controle desses processos, incluindo fatores de transcrição e proteínas relacionadas à apoptose. Objetivo - Neste artigo de revisão apresenta-se o conhecimento acerca do perfil genético deste subgrupo de tumor do esôfago, focando-se no potencial desenvolvimento de novas ferramentas para o tratamento clínico do carcinoma avançado de células escamosas do esôfago. Conclusões - O avanço no campo da biologia molecular tem permitido um maior conhecimento do processo de carcinogênese do esôfago, que deve resultar em benefícios aos pacientes com câncer. Desta forma, espera-se que um melhor entendimento das alterações moleculares durante a carcinogênese aumente o controle e a prevenção ao câncer e também possa levar ao tratamento melhorado da doença.

DESCRITORES - Neoplasias esofágicas, cirurgia. Carcinoma de células escamosas. Genes p53. Ciclo celular. Apoptose. 


\section{REFERENCES}

1. Anayama T, Furihata M, Takeuchi T, Sonobe H, Sasaguri S, Matsumoto M, Ohtsuki Y. Insufficient effect of p27(KIP1) to inhibit cyclin D1 in human esophageal cancer in vitro. Int J Oncol 2001;18:151-5.

2. Bahl R, Arora S, Nath N, Mathur M, Shukla NK, Ralhan R. Novel polymorphism in p21(waf1/cip1) cyclin dependent kinase inhibitor gene: association with human esophageal cancer. Oncogene 2000;19:323-8.

3. Bunz F, Dutriaux A, Lengauer C, Waldman T, Zhou S, Brown JP, Sedivy JM, Kinzler KW, Vogelstein B. Requirement for p53 and p21 to sustain G2 arrest after DNA damage. Science 1998;282:1497-501.

4. Caron de Fromental C, Soussi T. TP53 tumor suppressor gene: a model for investigating human mutagenesis. Genes Chromosomes Cancer 1992;4:1-15.

5. Chino O, Kijima H, Shimada H, Nishi T, Tanaka H, Kise Y, Kenmochi T, Himeno S, Machimura T, Tanaka M, Inokuchi S, Tajuma T, Osamura RY, Makuuchi H. Accumulation of $\mathrm{p} 53$ in esophageal squamous cell carcinoma. Int J Mol Med 2001;8:359-63.

6. el-Deiry WS, Tokino T, Velculescu VE, Levy DB, Parsons R, Trent JM, Lin D, Mercer E, Kinzler KW, Vogelstein B. WAF1, a potential mediator of p53 tumor suppression. Cell 1993;75:817-25.

7. el-Deiry WS, Harper JW, O'Connor PM, Velculescu VE, Canman CE, Jackman J, Pietenpol JA, Burrell M, Hill DE, Wang Y. WAF1/CIP1 is induced in p53mediated G1 arrest and apoptosis. Cancer Res 1994;54:1169-74.

8. Fujii S, Tominaga O, Nagawa H, Tsuno N, Nita ME, Tsuruo T, Muto T. Quantitative analysis of the cyclin expression in human esophageal cancer cell lines. J Exp Clin Cancer Res 1998;17:491-6.

9. Gomez-Manzano C, Fueyo J, Kyritsis AP, Steck PA, Roth JA, McDonnell TJ, Steck KD, Levin VA, Yung WK. Adenovirus-mediated transfer of the p53 gene produces rapid and generalized death of human glioma cells via apoptosis. Cancer Res 1996;56:694-9.

10. Iamamura M. Prognostic significance of Cyclin D1 and E-cadherin in patients with esophageal squamous cell carcinoma: multiinstitutional retrospective analysis. J Am Coll Surg 2001;192:708-18.

11. Ikeguchi M, Maeta M, Kaibara N. Bax expression as a prognostic marker of postoperative chemoradiotherapy for patients with esophageal cancer. Int J Mol Med 2001;7:413-7

12. Kato H, Yoshikawa M, Fukai Y, Tajima K, Masuda N, Tsukada K, Kuwano H, Nakajima T. An immunohistochemical study of p16, pRb, p21 and $\mathrm{p} 53$ proteins in human esophageal cancers. Anticancer Res 2000;20:345-9.

13. Lam KY, Law S, Tung PH, Wong J. Esophageal small cell carcinomas: clinicopathologic parameters, p53 overexpression, proliferation marker, and their impact on pathogenesis. Arch Pathol Lab Med 2000;124:228-33.

14. Lane DP. p53, guardian of the genome. Nature 1992;358:15-6.

15. Lane DP. A death in the life of p53. Nature 1993;362:786-7.

16. Lebman DA, Edmiston JS, Chung TD, Snyder SR. Heterogeneity in the transforming growth factor beta response of esophageal cancer cells. Int J Oncol 2002;20:1241-6.

17. Liggett WH Jr, Sidransky D. Role of the p16 tumor suppressor gene in cancer. J Clin Oncol 1998;16:1197-206.

18. Matsumoto M, Natsugoe S, Nakashima S, Okumura H, Sakita H, Baba M, Takao S, Aikou T. Clinical significance and prognostic value of apoptosis related proteins in superficial esophageal squamous cell carcinoma. Ann Surg Oncol 2001;8:598-604

19. Merlo A, Herman JG, Mao L, Lee DJ, Gabrielson E, Burger PC, Baylin SB, Sidransky D. 5' $\mathrm{CpG}$ island methylation is associated with transcriptional silencing of the tumour suppressor p16/CDKN2/MTS1 in human cancers. Nat Med 1995; 1:686-92.

20. Moraes-Filho J, Cecconello I, Gama-Rodrigues J, Castro L, Henry MA, Meneghelli UG, Quigley E, Brazilian Consensus Group. Brazilian consensus on gastroesophageal reflux disease: proposals for assessment, classification, and management. Am J Gastroenterol 2002;97:241-8.

21. Muñoz N. Epidemiological aspects of esophageal cancer. Endoscopy 1993; 23:609-12

22. Nagasawa S, Masahiko O, Sasajima K, Makino H, Yamashita K, Takubo K, Miyashita M. Cyclin D1 over expression as a prognostic factor in patients with esophageal carcinoma. J Surg Oncol 2001;78:208-14.
23. Nita ME, Nagawa H, Tominaga O, Tsuno N, Hatano K, Kitayama J, Tsuruo T, Domene CE, Muto T. p21Waf1/Cip1 expression is a prognostic marker in curatively resected esophageal squamous cell carcinoma, but not p27Kip1, p53, or Rb. Ann Surg Oncol 1999;6:481-8.

24. Nita ME. Role of apoptosis related proteins in digestive tract cancer [thesis]. Tokyo: The University of Tokyo; 2000

25. Nita ME, Ono-Nita SK, Tsuno N, Tominaga O, Takenoue T, Sunami E, Kitayama J, Nakamura Y, Nagawa H. Bcl-X(L) antisense sensitizes human colon cancer cell line to 5-fluorouracil. Jpn J Cancer Res 2000;91:825-32.

26. Ohbu M, Saegusa M, Kobayashi N, Tsukamoto H, Mieno H, Kakita A, Okayasu I. Expression of bcl-2 protein in esophageal squamous cell carcinomas and its association with lymph node metastasis. Cancer 1997;79:1287-93.

27. Okuda T, Shurtleff SA, Valentine MB, Raimondi SC, Head DR, Behm F, CurcioBrint AM, Liu Q, Pui C-H, Sherr CJ, Beach D, Look AT, Downing JR. Frequent deletion of p16(INK4a)/MTS1 and p15(INK4b)/MTS2 in pediatric acute lymphoblastic leukemia. Blood 1995;85:2321-30.

28. Oliner JD, Kinzler KW, Meltzer PS, George DL, Vogelstein B. Amplification of a gene encoding a p53-associated protein in human sarcomas. Nature 1992;358:80-3.

29. Oyama T, Kanai Y, Ochiai A, Akimoto S, Oda T, Yanagihara K, Nagafuchi A, Tsukita S, Shibamoto S, Ito F. A truncated -catenin disrupts the interaction between E-cadherin and -catenin: a cause of loss of intercellular adhesiveness in human cancer cell lines. Cancer Res 1994;54:6282-7.

30. Pennisi E. How a growth control path takes a wrong turn to cancer. Science 1998;281:1438-41.

31. Polyak K, Lee M-H, Erdjument-Bromage H, Koff A, Roberts JM, Tempst P, Massague J. Cloning of p27(Kip1), a cyclin-dependent kinase inhibitor and a potential mediator of extracellular antimitogenic signals. Cell 1994;78:59-66.

32. Ralhan R, Mathew R, Arora S, Bahl R, Shukla NK, Mathur M. Frequen alterations in the expression of tumor suppressor genes p16INK4A and $\mathrm{pRb}$ in esophageal squamous cell carcinoma in the Indian population. J Cancer Res Clin Oncol 2000;126:655-60.

33. Ribeiro U, Finkelstein SD, Safatle-Ribeiro AV, Landreneau RJ, Clarke MR, Bakker A, Swalsky PA, Gooding WE, Posner MC. p53 sequence analysis predicts treatment response and outcome of patients with esophageal carcinoma. Cancer 1998;83:7-18.

34. Ries SJ, Brandts CH, Chung AS, Biederer CH, Hann BC, Lipner EM, McCormick F, Korn WM. Loss of p14ARF in tumor cells facilitates replication of the adenovirus mutant d11520 (ONYX-015). Nat Med 2001;6:1128-33.

35. Robertson KD, Jones PA. Tissue-specific alternative splicing in the human INK4a ARF cell cycle regulatory locus. Oncogene 1999;18:3810-20.

36. Sherr CJ, Roberts JM. Inhibitors of mammalian G1 cyclin-dependent kinases. Genes Dev 1995;9:1149-63.

37. Si HX, Tsao SW, Lam KY, Srivastava G, Liu Y, Wong YC, Shen ZY, Cheung ALM. E-cadherin expression is commonly downregulated by $\mathrm{CpG}$ island hypermethylation in esophageal carcinoma cells. Cancer Letters 2001;173:71-8.

38. Sturm I, Petrowsky H, Volz R, Lorenz M, Radetzki S, Hillebrand T, Wolff G, Hauptmann S, Dorken B, Daniel PT. Analysis of 53/BAX/p16(ink4a/CDKN2) in esophageal squamous cell carcinoma: high BAX and p16(ink4a/CDKN2) identifies patients with good prognosis. J Clin Oncol 2001;19:2272-81.

39. Tanaka H, Shimada Y, Imamura M, Shibagaki I, Ishizaki K. Multiple types of aberrations in the p16 (INK4a) and the p15(INK4b) genes in 30 esophageal squamous-cell-carcinoma cell lines. Int J Cancer 1997;70:437-42.

40. Tetsu O, McCormick F. $\beta$-catenina regulates expression of ciclyn D1 in colon carcinoma cells. Nature 1999;398:422-6.

41. Vogelstein B, Kinzler KW. p53 function and dysfunction. Cell 1992;70:523-6.

42. Xing EP, Nie Y, Song Y, Yang GY, Cai YC, Wang LD, Yang CS. Mechanisms of inactivation of p14ARF, p15INK4b, and p16INK4a genes in human esophageal squamous cell carcinoma. Clin Cancer Res 1999;5:2704-13.

43. Xing EP, Nie Y, Wang LD, Yang GY, Yang CS. Aberrant methylation of p16INK4a and deletion of p15INK4b are frequent events in human esophageal cancer in Linxian, China. Carcinogenesis 1999;20:77-84

44. Yoshiura K, Kanai Y, Ochiai A, Shimoyama Y, Sugimura T, Hirohashi S. Silencing of the E-cadherin invasion-supressor gene by $\mathrm{CpG}$ methylation in human carcinomas. Proc Natl Acad Sci USA 1995;92:7416-9.

Recebido em 7/5/2003. Aprovado em 3/7/2003. 